https://doi.org/10.15407/ukrbotj75.06.564

\title{
DNA extraction from old herbarium material of Veronica subgen. Pseudolysimachium (Plantaginaceae)
}

\author{
Jannes HÖPKE ${ }^{1}$, Grace BREWER ${ }^{2}$, Steven DODSWORTH ${ }^{2,3}$, Edgardo M. ORTIZ ${ }^{4}$, Dirk C. ALBACH ${ }^{1}$ \\ ${ }^{1}$ Institute of Biology and Environmental Sciences, Carl von Ossietzky University Oldenburg \\ D-26111 Oldenburg, Germany \\ ${ }^{2}$ Royal Botanic Gardens, Kew \\ Richmond TW9 3DS, UK \\ ${ }^{3}$ School of Life Sciences, University of Bedfordshire \\ Luton LU1 3JU, UK \\ ${ }^{4}$ Technical University of Munich, Department of Ecology \& Ecosystem Management \\ Emil-Ramann Strasse 2, D-85354 Freising, Germany
}

Höpke J., Brewer G., Dodsworth S., Ortiz E.M., Albach D.C. DNA extraction from old herbarium material of Veronica subgen. Pseudolysimachium (Plantaginaceae). Ukr. Bot. J., 2018, 75(6): 564-575.

\begin{abstract}
Herbarium specimens have become a major source of information in molecular biodiversity research, framing the term "herbarium genomics". However, obtaining good DNA from old herbarium specimens is still a challenge. Currently, DNA extraction methods from old herbarium material often yield highly degraded and fragmented DNA. A number of studies have discussed such methods, especially how to avoid further DNA fragmentation. This study aims to compare different DNA extraction methods applied to old herbarium material from Veronica subg. Pseudolysimachium. One such method is a CTABbased DNA extraction followed by a clean-up with paramagnetic beads that is used in the Jodrell Laboratory, Royal Botanic Gardens Kew, UK. This method was compared to a modified NucleoSpin Plant II protocol, based on silica columns, as used at the Technical University Munich-Freising, which was already successfully used for extracting DNA from a Linnean type specimen. Further tests were conducted on the influence of incubation time on the CTAB DNA extraction protocol with a subsample of specimens. Our preliminary results suggest that CTAB DNA extraction might have some advantages in specific cases but also that silica column-based methods have fewer problems with contamination by polysaccharides and polyphenolic compounds. Regarding the incubation time, we did not observe a clear pattern, but we developed several ideas on how to proceed with tests to find an optimal DNA extraction protocol to deal with highly fragmented DNA. Taking practical considerations into account, the column-based method proves to be preferable, especially when trying to reduce the amount of leaf tissue used, but further modifications of both methods should be explored.
\end{abstract}

Keywords: Veronica subg. Pseudolysimachium, herbarium specimens, DNA extraction methods, molecular biodiversity research

Supplementary Material. Electronic Supplement (Table E1, p. e3) is available in the online version of this article at: https://ukrbotj.co.ua/archive/75/6/564

\section{Introduction}

Research on natural biodiversity is often obscured by being forced "to work in suboptimal conditions that include inadequate preservation methods, limited sampling regimes, and suboptimal tissue type and quantity" (Blair et al., 2015: 1079-1080). Nevertheless, it is possible to overcome the problem of inaccessibility of specimens by using herbarium material, which is a valuable source of DNA (Staats et al., 2011), to clarify a multitude of various questions. However, the bigger

(C) J. HÖPKE, G. BREWER, S. DODSWORTH, E.M. ORTIZ, D.C. ALBACH, 2018 problem is that herbarium DNA is usually highly degraded and modified (Staats et al., 2011) and that the small amounts of DNA can be a limiting factor in downstream applications like high-throughput sequencing (= HTS; Lovmar, Syvänen, 2006; Lasken, 2009). Therefore, several methods have been developed for DNA extraction of herbarium specimens (Záveská Drábková, 2014), which sometimes deal with taxonspecific problems and sometimes have taxon-specific success rates.

In our project to investigate the status of several "microspecies" of Veronica subg. Pseudolysimachium (W.D.J.Koch) Buchenau from the eastern part of 
Ukraine, for which a plethora of names have been described (Klokov, 1976; Tzvelev, 1981; Ostapko, 1984, 1994, 2014; Ostapko et al., 2010), herbarium material is a vital resource since it proves difficult to collect new material, especially for Donetsk Region (Oblast in Ukrainian), Luhansk Region, and the Crimean Peninsula due to the current political and military situation. Therefore, this project will focus on herbarium material and, furthermore, demonstrate the feasibility to retrieve DNA from type material to clarify the relationships of the described species and infraspecific entities.

Therefore, we compared DNA extraction methods from two labs, the Jodrell Laboratory at the Royal Botanic Gardens (Kew, UK), and the laboratory of Prof. Dr. Hanno Schaefer, Technical University Munich-Freising, (Germany). Both labs have extensive experience in DNA extraction from herbarium specimens (e.g., Dodsworth, 2015; Schaefer et al., 2009; Dwivedi et al., 2018). We were particularly interested in exploring those methods used in regular molecular biology laboratories without specialized ancient DNA facilities, which requires a lot of time, money, and institutional support (Knapp et al., 2012).

DNA extraction at Kew was formerly conducted using a "macroprep protocol" as described in Albach and Chase (2001). This protocol is based on the strong detergent cetyltrimethyl ammonium bromide (CTAB) (Kistler, 2012), which has been the "gold standard" for plant DNA extractions since the mid-1980s (Doyle, Doyle, 1987; Rogers, Bendich, 1985). This is followed by a DNA cleaning step using chloroform and isoamyl alcohol for removing proteins (Albach, Chase, 2001) and an isopycnic ultracentrifugation in cesium chloride, meaning that the molecules will be separated according to their density. This method has typically been used to separate the plastid/mitochondrial DNA from nuclear DNA (Carr, Griffith, 1987) to avoid analyzing numts (= nuclear mitochondrial DNA segment, DNA which was transferred from the mitochondrial to the nuclear genome) since they present a different evolutionary fate (Arthofer et al., 2010). While this yields ultrapure DNA suitable for long-term storage especially recommendable for DNA from type material, Kew has replaced the expensive and time-consuming technique for many projects in favor of a modified CTAB DNA extraction protocol similar to the original CTAB protocol proposed by Doyle and Doyle (1990). The protocol was modified by subsequent cleaning with Solid Phase Reversible Immobilization beads (= SPRI), which are paramagnetic beads, i.e. they are just magnetic in a magnetic field. These beads are polystyrene coated with a layer of magnetite and carboxyl molecules on top, which can reversibly bind DNA in the presence of polyethylene glycol (a crowding agent) and salt (DeAngelis et al., 1995).

This method was compared with a modified "NucleoSpin II Plant" (Macherey-Nagel Inc., Düren, Germany) mini DNA extraction protocol (Schaefer et al., 2009; Dwivedi et al., 2018). This commercial kit was already successfully used in a study to extract DNA from a Linnean type specimen (Chomicki, Renner, 2015). In this respect, it should be noted that a number of different commercial plant DNA extraction kits based on silica-membrane methods are available. These kits do differ in specifics and may, therefore, differ in their suitability for DNA extraction from herbarium specimens and/or different taxa, which we noticed in preliminary tests (Dirk C. Albach, unpublished data). Finally, we explored the effect of extending the incubation time since different taxa work better with different incubation times during lysis (Edgardo M. Ortiz, unpublished data; Drábková et al., 2002).

Numerous other modifications have been reported to improve DNA extraction from herbarium specimens, such as PTB-buffer extraction (Kistler, 2012) and an extended precipitation (Staats et al., 2011). Another alternative is whole genome amplification such as the "Restriction and Circularization-Aided Rolling Circle Amplification" (= RCA-RCA) method described by Wang et al. (2004) that shows promising results when working with highly degraded template DNA, according to Blair et al. (2015). For a similar method multiple displacement amplification (MDA), feasibility has been already shown to produce enough DNA as a starting point for "restriction site associated" sequencing methods (Blair et al., 2015). The RCA-RCA method is considered to be superior to the already tested MDA since it does not produce non-specific amplification artefacts (Blair et al., 2015, also in the absence of input genomic DNA), as it was reported for MDA, which is crucial when working with low DNA input (Lage et al., 2003). The MDA method also faces problems with short fragments (Steven Dodsworth, unpublished data), which is congruent with findings that MDA is not able to replicate fragments below $1 \mathrm{kbp}$ ( $\mathrm{Li}$ et al., 2006; Maciejewska et al., 2013). However, testing of these additional methods is beyond the scope of the current project. Our preliminary results (see Höpke, Albach, 2018) were briefly reported at the International Conference 'Herbaria and Phytodiversity Conservation' (3-5 October 2018, Lviv, Ukraine). Here we provide a full report. 


\section{Material and Methods}

\section{Sampling material}

The two DNA extraction methods were tested on samples from our focal taxonomic group Veronica subg. Pseudolysimachium. Samples were taken from the herbarium in Oldenburg and from leaf samples that had already been collected for DNA extractions (from herbarium sheets and silica dried leaves). The samples were chosen to fit two mini centrifuges, i.e. 48 samples, and to include a homogeneous sampling of all available decades of collection. From Veronica subg. Pseudolysimachium, sampling included two specimens available from the 1950s, two from the 1960 s, nine from the 1970s, one from the 1980s, five from the 1990s, ten from the 2000s, and ten from the last decade. Since the availability of old material from this subgenus was restricted, we supplemented this with Veronica specimens from other subgenera as follows: two specimens from the 1950s, 11 from the 1970s, four from the 1980s, and three from the 1990s. From these samples, c. $20 \mathrm{mg}$ of leaf tissue was taken for CTAB DNA extraction and $10 \mathrm{mg}$ for column-based DNAextraction with subsequent standardization of results.

We took additional samples for the incubation time analysis. For this, twice c. $10 \mathrm{mg}$ leaf samples from ten herbarium sheets from different decades (each) was taken: one from the 1950s, one from the 1960s, two from the 1970s, one from the 1980s, one from the 1990s, two from the 2000s, and two from the last decade. With these, two different incubation times were tested during lysis. Information on all specimens used in the analysis can be found in the Electronic Supplement (Table E1.).

\section{CTAB and bead clean-up}

The preparation and DNA extraction were conducted in a sodium hypochlorite-cleaned fume hood (designated for DNA extraction only) with sodium hypochlorite-cleaned equipment and pipettes used with filter tips only. For the CTAB mini protocol, one liter of 2x CTAB buffer was prepared as follows: $12.11 \mathrm{~g}$ TRIS/TRIZMA (100 mM final concentration), was dissolved in a small amount of distilled water using an agitator and magnetic stirrer. To this $7.5 \mathrm{~g}$ EDTA (20 $\mathrm{mM})$ was added, filled up with distilled water to $0.5 \mathrm{~L}$, and adjusted to a $\mathrm{pH}$ of 8.0. Afterwards, $82 \mathrm{~g}$ $\mathrm{NaCl}(1.4 \mathrm{M}), 20 \mathrm{~g} \mathrm{CTAB}(2 \% \mathrm{w} / \mathrm{v})$, and $20 \mathrm{~g}$ PVP $(2 \% \mathrm{w} / \mathrm{v})$ were added but dissolved one after another and finally filled up with distilled water to $1 \mathrm{~L}$. Firstly, for the DNA extraction protocol, isopropanol and the blocks of the grinder were put into a freezer at $20^{\circ} \mathrm{C}$ and

a water bath was preheated to $65^{\circ} \mathrm{C}$. The lysis buffer was prepared by mixing $747 \mu \mathrm{L} 2 \mathrm{x}$ CTAB buffer per sample with $3 \mu \mathrm{L}$ of 2 -mercaptoethanol (equaling $0.4 \%$ of the isolation buffer) and $3 \mu \mathrm{L}$ of $10 \mathrm{mg} / \mathrm{mL}$ RNAse A. Each sample $(20 \mathrm{mg})$ was then ground with two steel balls (c. $4 \mathrm{~mm}$ in diameter) within the precooled grinder blocks (to prevent overheating and enzymatic activity) at 25,000 rpm for 2 min using a Retsch MM400 (Retsch Inc., Haan, Germany). Immediately afterwards, $750 \mu \mathrm{L}$ freshly prepared lysis buffer was added, vortexed for $3 \mathrm{sec}$ and incubated for $30 \mathrm{~min}$ in a water bath at $65{ }^{\circ} \mathrm{C}$. Every $5 \mathrm{~min}$ the samples were mixed by hand. Afterwards, $750 \mu \mathrm{L}$ SEVAG (chloroform : isoamyl alcohol $24: 1$ ) was added, vortexed for $3 \mathrm{sec}$ and the sample tubes were attached with a tape onto a shaker platform, here an Orbital Shaker Model SO3 (ColeParmer Inc., Stone, United Kingdom), running at $250 \mathrm{rpm}$. After $30 \mathrm{~min}$, the samples were centrifuged at $13,000 \mathrm{rpm}$ for $15 \mathrm{~min}, 550 \mu \mathrm{L}$ of the supernatant above the protein pellet was transferred into a new $2.0 \mathrm{~mL}$ microcentrifugation-tube, $367 \mu \mathrm{L}$ of $-20{ }^{\circ} \mathrm{C}$ precooled isopropanol ( $2 / 3$ of the supernatant volume) was added, the samples were vortexed for $3 \mathrm{sec}$ and shortly centrifuged so that all droplets moved to the bottom of the tube and kept overnight in the freezer at $-20{ }^{\circ} \mathrm{C}$.

At the beginning of the next day Qiagen AE elution buffer (Qiagen Inc., Venlo, Netherlands) was preheated to $65{ }^{\circ} \mathrm{C}$. Samples in isopropanol were centrifuged at 13,000 rpm for $15 \mathrm{~min}$, the aqueous phase was decanted, the DNA pellet was washed by adding $750 \mu \mathrm{L}$ of freshly prepared $70 \%$ ethanol, centrifuged at $13,000 \mathrm{rpm}$ for 10 min, decanting the ethanol and washing it in the same way a second time. All ethanol was removed, the pellet was dried by placing the samples with opened lids in a GeneVac miVac Duo Concentration, operating with a Duo Pump (Thermo Fisher Scientific Inc., Waltham, MA, USA) at $46{ }^{\circ} \mathrm{C}$ for 5 min (drying overnight under the fume hood is also possible). Then, $100 \mu \mathrm{L}$ of the preheated elution buffer was added to each sample, the pellet was thoroughly resuspended and shortly centrifuged, the samples were incubated at $65{ }^{\circ} \mathrm{C}$ in the water bath for $30 \mathrm{~min}$, vortexed for $3 \mathrm{sec}$, and again shortly centrifuged.

The bead clean-up was conducted on a normal molecular lab workbench by adding two times the eluted DNA volume $(200 \mu \mathrm{L})$ of the undiluted AMPure XP bead solution (Beckman Coulter, Brea, CA, USA) to the eluted DNA. This DNA-bead solution was mixed, spun down shortly and incubated at room temperature (RT) for $5 \mathrm{~min}$. Afterwards the tubes were placed in a 
12-tube magnetic separation rack for $1.5 \mathrm{~mL}$ tubes (New England BioLabs Inc., MA, USA). After 5 min or longer until the solution becomes clear and a pellet was formed, the supernatant was removed and discarded, and the pellet was washed twice by adding $300 \mu \mathrm{L}$ of freshly prepared $80 \%$ ethanol, which was left for $30 \mathrm{sec}$ before being removed. Subsequently all the ethanol was removed, the pellet dried for $5 \mathrm{~min}$ and thoroughly resuspended in $60 \mu \mathrm{L} \mathrm{AE}$ elution buffer, spun down shortly and incubated for $5 \mathrm{~min}$ at RT on a normal rack, and then for $5 \mathrm{~min}$ at RT on the magnetic rack. Finally, $50 \mu \mathrm{L}$ of the aqueous phase containing the clean DNA was transferred to a new tube.

\section{Quality control A}

For the CTAB-bead DNA extraction, a QuantiFluor dsDNA System (Promega Inc., Fitchburg, WI, USA) was used to measure the dsDNA concentration. Here, 20x TE buffer was diluted to $1 \mathrm{x}$ before use. The standard was prepared with $2 \mu \mathrm{L}$ standard solution, $98 \mu \mathrm{L} \mathrm{1x}$ TE and $100 \mu \mathrm{L}$ dye; the blank was prepared with $100 \mu \mathrm{L}$ $1 \mathrm{xTE}$ and $100 \mu \mathrm{L}$ dye, and the samples were prepared with $1 \mu \mathrm{L}$ DNA solution, $99 \mu \mathrm{L} 1 \mathrm{xTE}$ and $100 \mu \mathrm{L}$ dye. A Quantus Fluorometer (Promega Inc., Fitchburg, WI, USA) was first calibrated using the standard and the blank before measuring the concentration of the samples. To measure the A260/A280 and A260/A230 absorbance ratios, a Nanodrop 2000 (Thermo Fisher Scientific, Waltham, MA, USA) was used by measuring $1 \mu \mathrm{L}$ Qiagen AE elution buffer (Qiagen Inc., Venlo, Netherlands) for calibration and afterwards $1 \mu \mathrm{L}$ DNA solution of each sample.

\section{Extended incubation times}

The effect of an extended incubation time was tested by incubating the samples in PHMT thermoshakers (Grant Instruments Inc., Cambridge, United Kingdom) at 400 rpm and $65^{\circ} \mathrm{C}$ during lysis with one sample set for $2 \mathrm{~h}$ and the other one for $4 \mathrm{~h}$ to compare with our standard 30 minutes. Since these tests were conducted in a different lab, there were a number of differences apart from incubation times. First, HighPrep PCR cleanup beads (MagBio Inc., Gaithersburg, MD, USA) were used instead of AMPure XP beads. Furthermore, the non-heated PHMT thermoshaker was used with samples taped on top of it and running at $550 \mathrm{rpm}$ to yield a similar shaking result when mixing samples with the SEVAG solution (compared to the Orbital Shaker SO3 at $250 \mathrm{rpm}$ ). Moreover, the samples were eluted using an elution buffer from a different company (Macherey-Nagel, Düren, Germany).

\section{Column-based DNA extraction}

Column-based DNA extraction was conducted in a $70 \%$ ethanol-cleaned fume hood with $70 \%$ ethanolcleaned equipment and pipettes used with filter tips only. Samples $(10 \mathrm{mg})$ were grinded at RT together with three steel balls (c. $3 \mathrm{~mm}$ in diameter) and half a $3 \mathrm{~mm}$ spoon of fine silica $(<0.5 \mathrm{~mm})$ stepwise (to prevent overheating) with $1500 \mathrm{rpm}$ for $20 \mathrm{sec}$ using a Retsch MM400 (Retsch Inc., Haan, Germany). Overall, all samples needed at least $60 \mathrm{sec}$ of grinding to yield a fine powder. Samples were stored at $-20{ }^{\circ} \mathrm{C}$ until further use DNA was extracted using the NucleoSpin Plant II mini kit following the manufacturer's protocol (Macherey-Nagel, Düren, Germany) with SDS as a lysis buffer (using buffers PL2 and PL3) except for some small modifications: For cell lysis no RNAse was used and incubation was conducted at a slightly lower temperature $\left(62{ }^{\circ} \mathrm{C}\right)$ with an increased incubation time (40 min) in a PHMT thermoshaker (Grant Instruments Inc., Cambridge, United Kingdom) at 500 rpm. For the clarification of the lysate the centrifugation time was increased to $5 \mathrm{~min}$ and no filter column was used (since the membrane often got blocked by the cell fragments). Instead the clear supernatant was transferred to a $1.5 \mathrm{~mL}$ tube and mixed with $350 \mu \mathrm{L}$ binding buffer before loading on the column. Furthermore, centrifugation was increased to 2 minutes. DNA was eluted in two steps with $25 \mu \mathrm{L}$ elution buffer. Finally, all remaining ethanol was allowed to evaporate thoroughly (c. $45 \mathrm{~min}$ ).

\section{Quality control B}

Concentration of column-based dsDNA extracts were analyzed on a Qubit dsDNA HS assay kit with a dye/ buffer premix (Thermo Fisher Scientific, Waltham, MA, USA). Standards 1 and 2 were prepared with 190 $\mu \mathrm{L}$ dye/buffer premix and $10 \mu \mathrm{L}$ standard solution, each; the samples were prepared with $198 \mu \mathrm{L}$ dye/ buffer premix and $2 \mu \mathrm{L}$ DNA solution, each. Both standards were used to calibrate the Qubit 4 fluorometer (Thermo Fisher Scientific, Waltham, MA, USA) before measuring each sample. For measuring the A260/A280 and A260/A230 absorbance ratios an Epoch Microplate Spectrophotometer (BioTek Inc., Winooski, VT, USA) was used by firstly calibrating the system using $2 \mu \mathrm{L}$ of PE buffer (Macherey-Nagel, Düren, Germany), and then $2 \mu \mathrm{L}$ of DNA solution per sample was measured.

\section{Statistical analysis}

To calculate the total dsDNA yield, the dsDNA concentration was multiplied by the final elution 


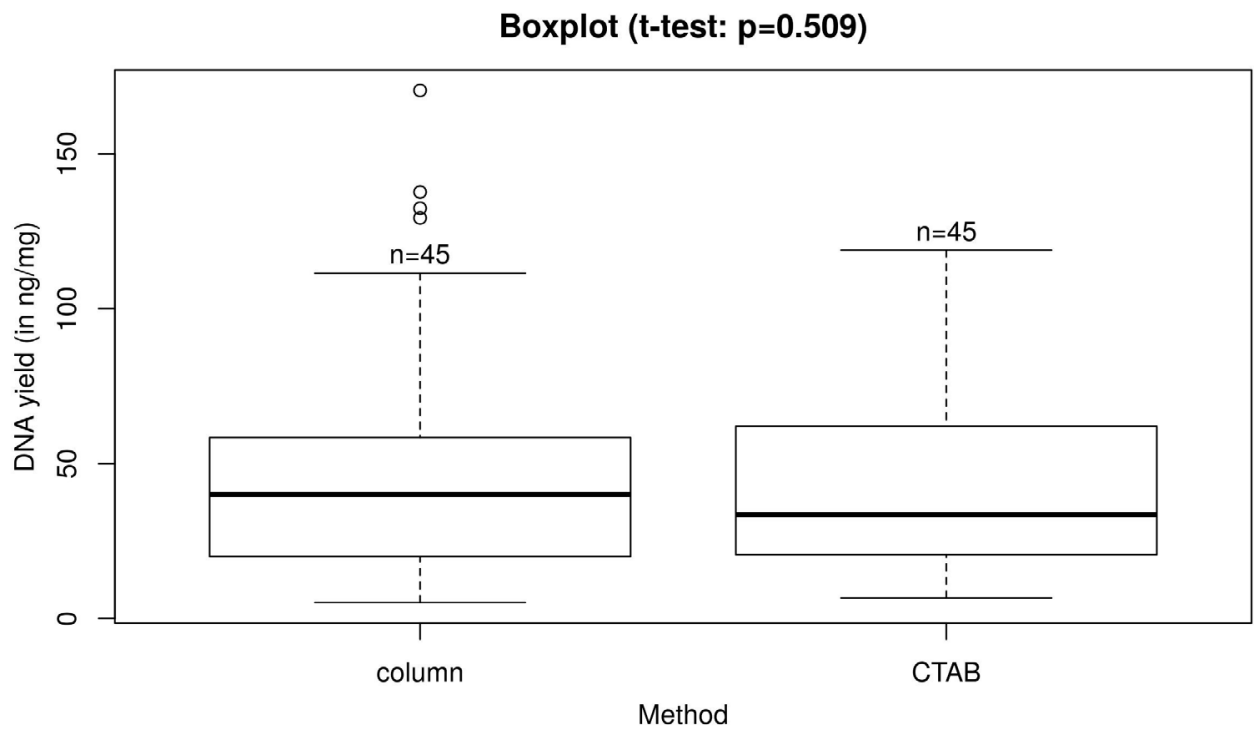

Fig. 1. Boxplot for DNA yield against extraction method (between column-based extraction and CTAB method)

volume. This value was then standardized by dividing the total dsDNA yield by the leaf dry mass used, which provided an estimate of the "DNA yield" (in ng of DNA per mg of used dried leaf tissue). For this parameter as well as the absorbance ratios A260/A280 and A260/ A230 (after removing 'not available data') AN(C)OVAs were conducted to test the relationships between the year of collection, sample type, subgenus and extraction method before focusing on the latter. The Shapiro-Wilk test and Levene test were used to assess the $\mathrm{AN}(\mathrm{C})$ OVA assumptions for normality and homoscedasticity (Dormann, Kühn, 2009). Even though these assumptions were often not met, AN(C)OVAS were used since they are used for data-inspection. When the assumptions for normality and homoscedasticity were met, a Tukey-HSD posthoc test was done but when the assumptions were not met, additional Kruskal-Wallis rank-sum tests and the Dunn test that uses a Bonferroni p-value adjustment method as a posthoc test (Dunn, 1964) were conducted. For pairwise comparisons t-tests were used when $\mathrm{AN}(\mathrm{C}) \mathrm{OVA}$ assumptions were met, and if the assumptions were not met, a Wilcoxon rank sum test was conducted instead.

\section{Results}

\section{DNA yield}

DNA yield was not influenced by taxonomy, as indicated by a non-significant Dunn test $(\alpha>0.05)$ and inspecting the corresponding boxplot (result not shown).
Comparing the DNA yield of both methods excluding two extreme outliers each, for which apparently some DNA was lost along the way, a paired t-test did not reveal a significant difference $(p=0.509)$. The column basedmethod had only a higher median DNA yield value with $40.1 \mathrm{ng} / \mathrm{mg}$ and some additional high "outliers" (above the whiskers that are defined with 1.5 times the interquartile range), whereas the CTAB-method had a median value of $33.5 \mathrm{ng} / \mathrm{mg}$ (Fig. 1).

Since we were interested to know if the year of collection might have an influence on DNA yield (not found in the ANCOVAs), a scatterplot was used to visualize the relationship between the DNA yield of both methods and the year of collection. Although the assumptions for the two independent linear regressions were fulfilled, the adjusted R2 values for both are below 0.08 and the scatter plot also does not reveal any clear pattern (Fig. 2). Including values for some specimens extracted only with one method, a tendency for DNA yield being lower was observed in older material but the unbalanced sampling and the low adjusted R2 value (0.07) have to be kept in mind (Fig. 2).

\section{DNA quality}

The ANCOVA for A260/A280 did not meet the statistical assumptions (even after reducing the model to significant variables only) but implies that the year of collection $(\mathrm{p}=0.003)$ and DNA extraction method $(\mathrm{p}<0.001)$ have an important influence. Here, 


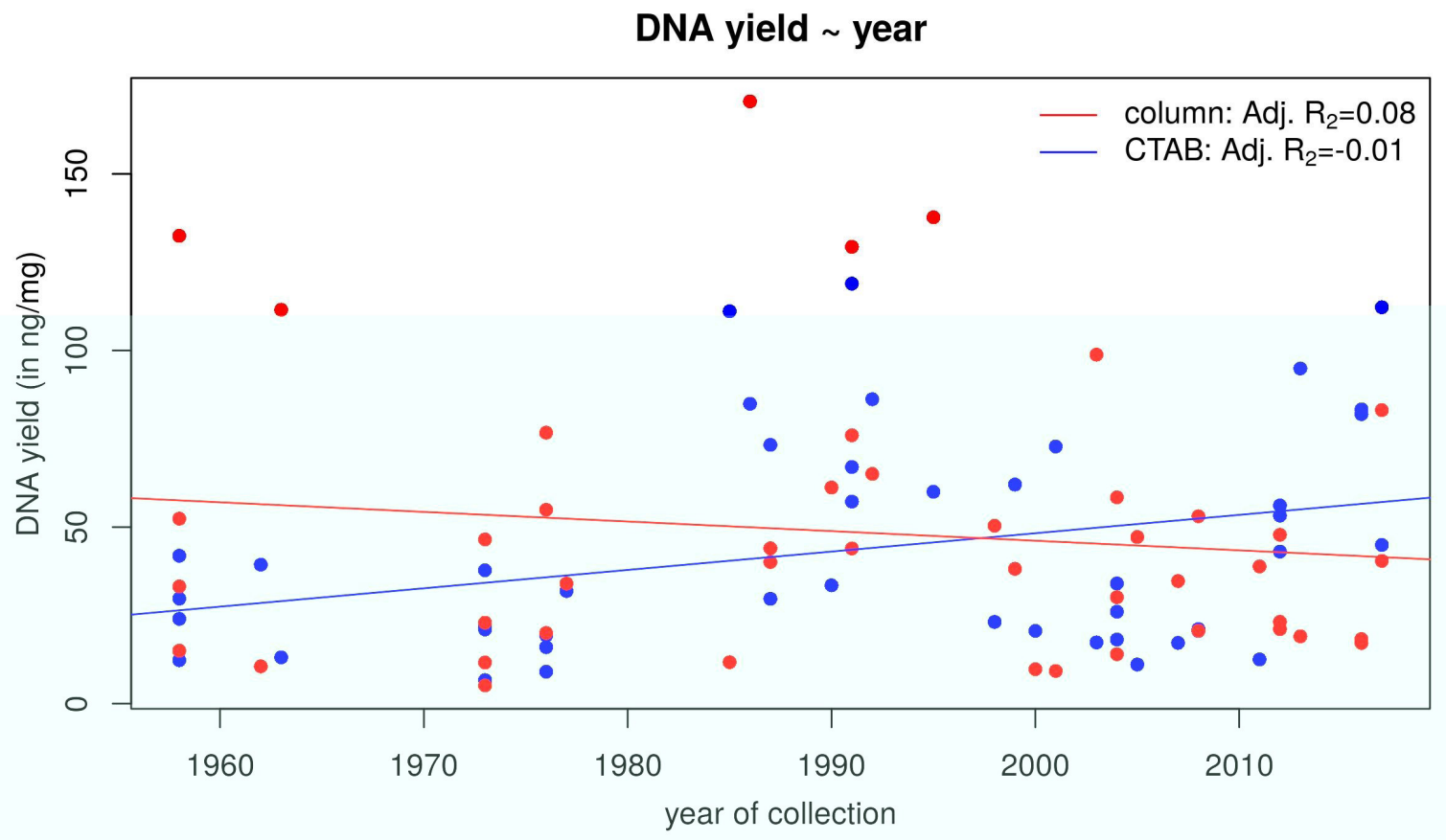

Fig. 2. Scatterplot for DNA yield against extraction method and year of collection (between CTAB and column-based extraction)

although the ANCOVA has a low R2 value, the plot shows that the A260/A280 ratio increases with the year of collection for both methods and that the columnbased method is c. 0.1 above the CTAB-based method (Fig. 3A). Statistical assumptions were likewise not met for the ANCOVA of A260/A230, but it suggests that the extraction method $(\mathrm{p}<0.001)$ is the only important variable. Furthermore, it shows, although weakly, that A260/A230 values for the two different sample types are different $(p=0.06)$. However, testing this explicitly using a Wilcoxon rank sum test (since the assumptions of a t-test were not fulfilled) no significant difference $(p=0.1759)$ was observed (Fig. 4).

For comparing the absorbance ratios, the previously removed observations were not removed here since they had no special placement in their scatter plots. Comparing both methods for A260/A280, a paired t-test showed they were significantly different. Here, column-based extraction showed a higher median ratio (2.04) than the CTAB method with 1.94. Also, the range of values for CTAB (1.54 to 2.24) was much wider than for column-based extractions (1.77 to 2.13) (Fig. 3B).

For A260/A230 values, a similar picture can be observed; although the difference is more extreme (e.g., the median of column-based extraction is 2.21 and for CTAB just 1.29). A paired t-test also showed this difference was significant ( $p<0.001)$ (Fig. 5).

\section{Incubation time}

Investigating the influence of the prolonged incubation time for the CTAB-based DNA extraction protocol, it was shown that the DNA yield, as well as A260/A280 and A260/A230 decrease with increased incubation time. Interestingly, the decrease is not gradual. Instead, the middle incubation time (of $2 \mathrm{~h}$ ) exhibits the minimum values for both DNA yield and A260/A280 ratios (Fig. 6).

\section{Discussion}

\section{CTAB with bead clean-up vs. column-based DNA extraction}

Statistical analysis did not reveal a significant difference in DNA yield between the two DNA extraction methods (Fig. 1), which were considered the most important criterion in this study. Other parameters seem to be more important such as initial sample drying process (Staats et al., 2011; Záveská Drábková, 2014) as well as the length of storage and fungi treatments during that time. Although initially counter-intuitive, we did not find a correlation of DNA yield with age. However, such a relationship was also not found in other studies (Choi et al., 2015; Shepherd, 2017), suggesting that DNA is stable if the plants are well stored and dried appropriately to start with. 

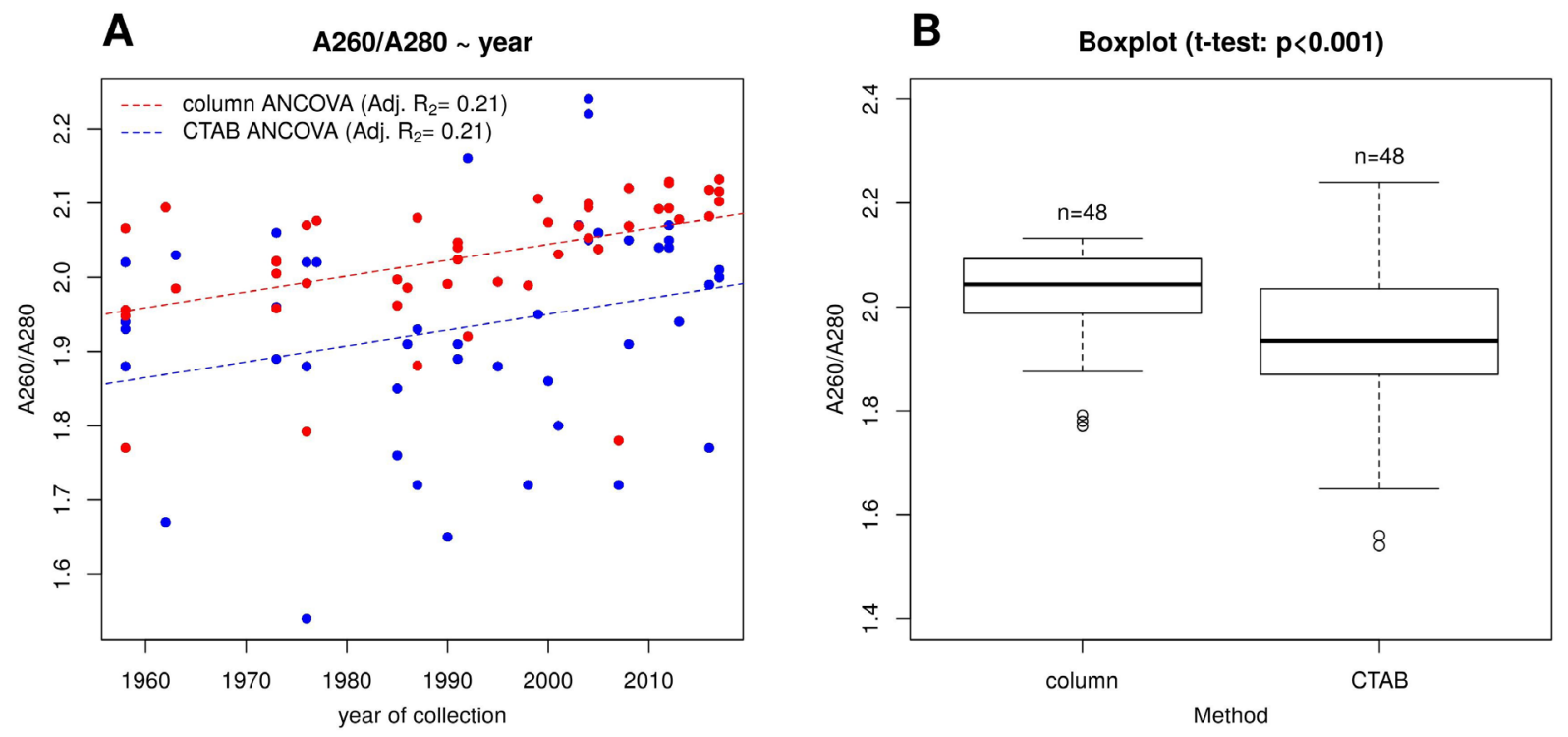

Fig. 3. Comparison of results for A260/A280 against extraction method (between CTAB and column-based method)

A: ANCOVA for extraction method and year of collection as covariate; B: Boxplot for A260/A280 against extraction method

Box plot (Wilcoxon rank sum test: $p=0.176$ )

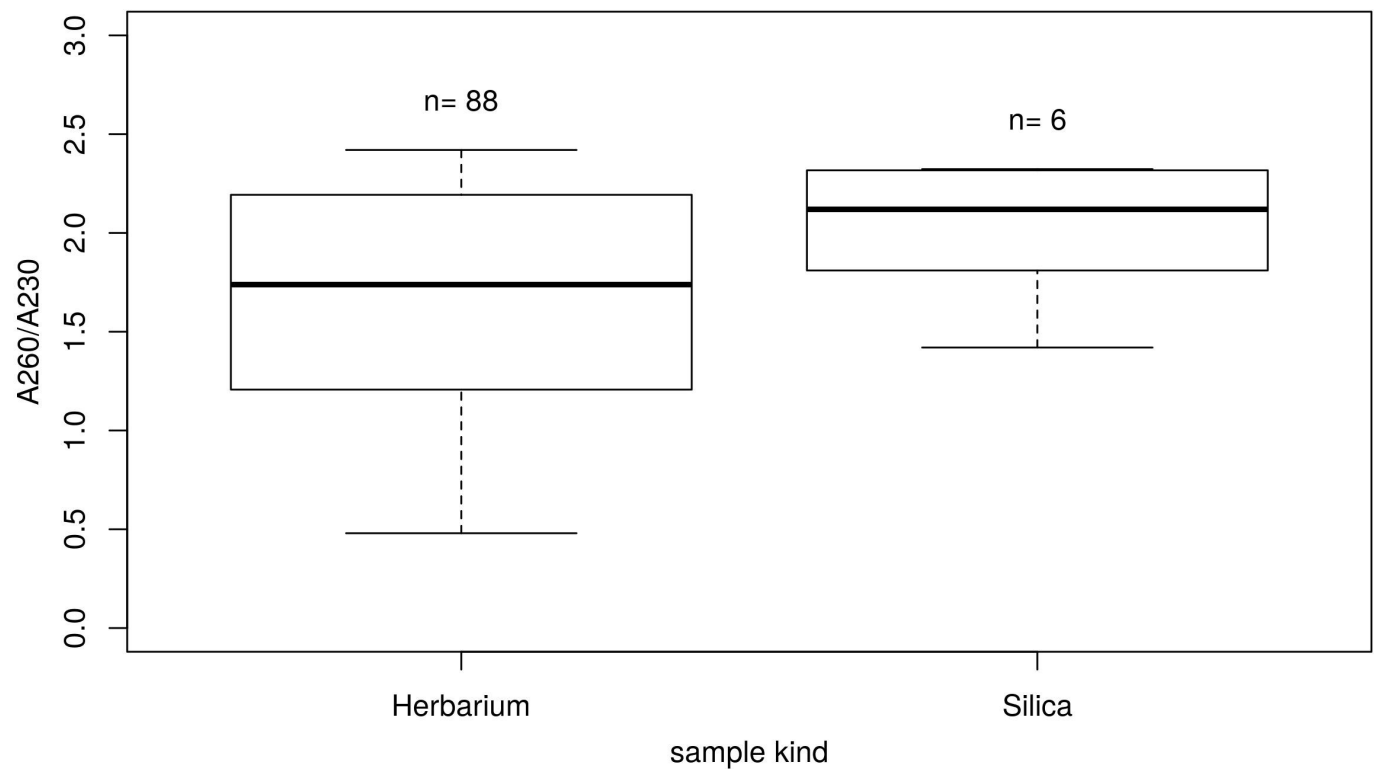

Fig. 4. Boxplot for A260/A230 against sample kind (for both DNA extraction methods combined) 


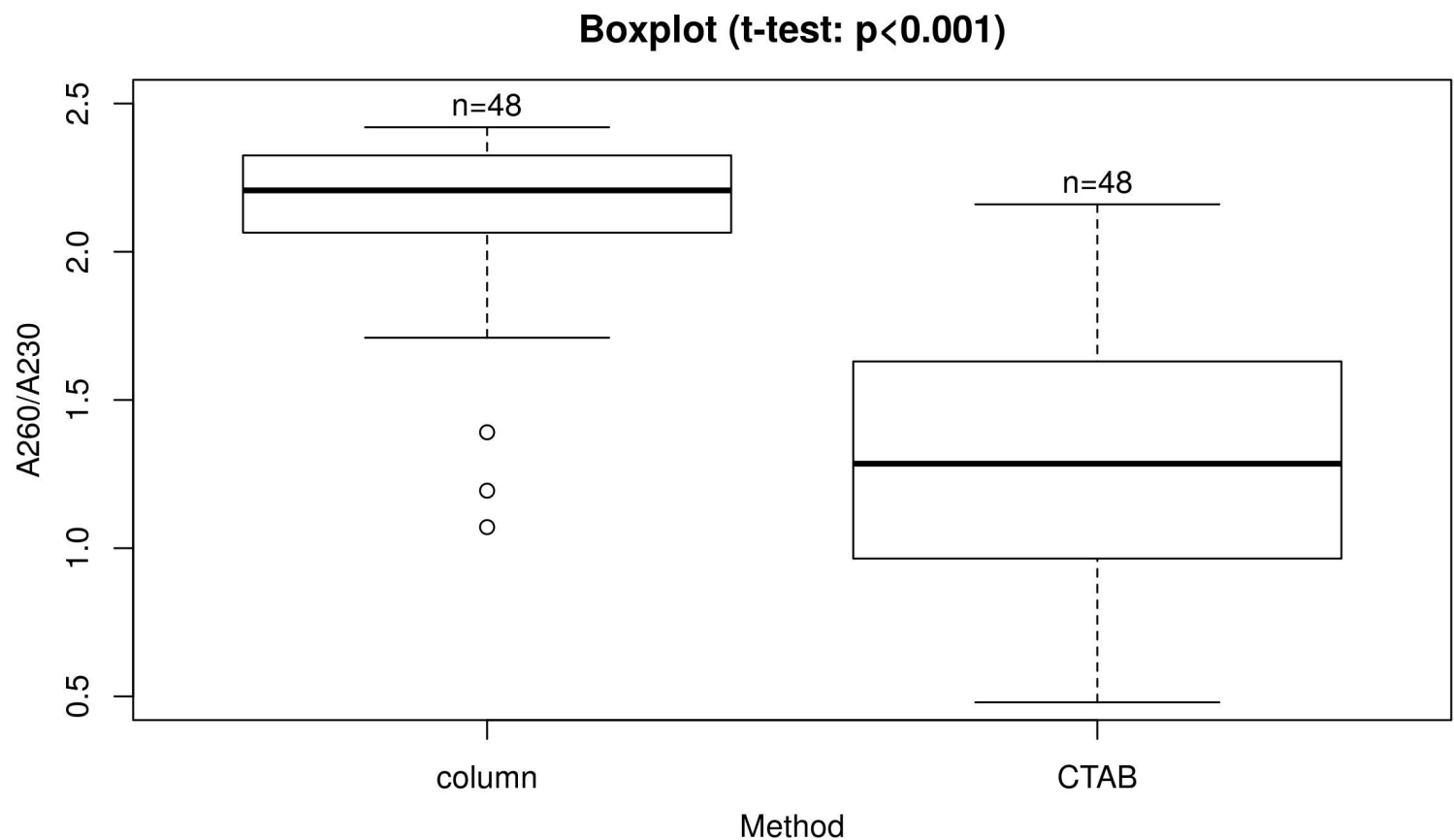

Fig. 5. Boxplot for A260/A230 against extraction method (between CTAB and column-based extraction)

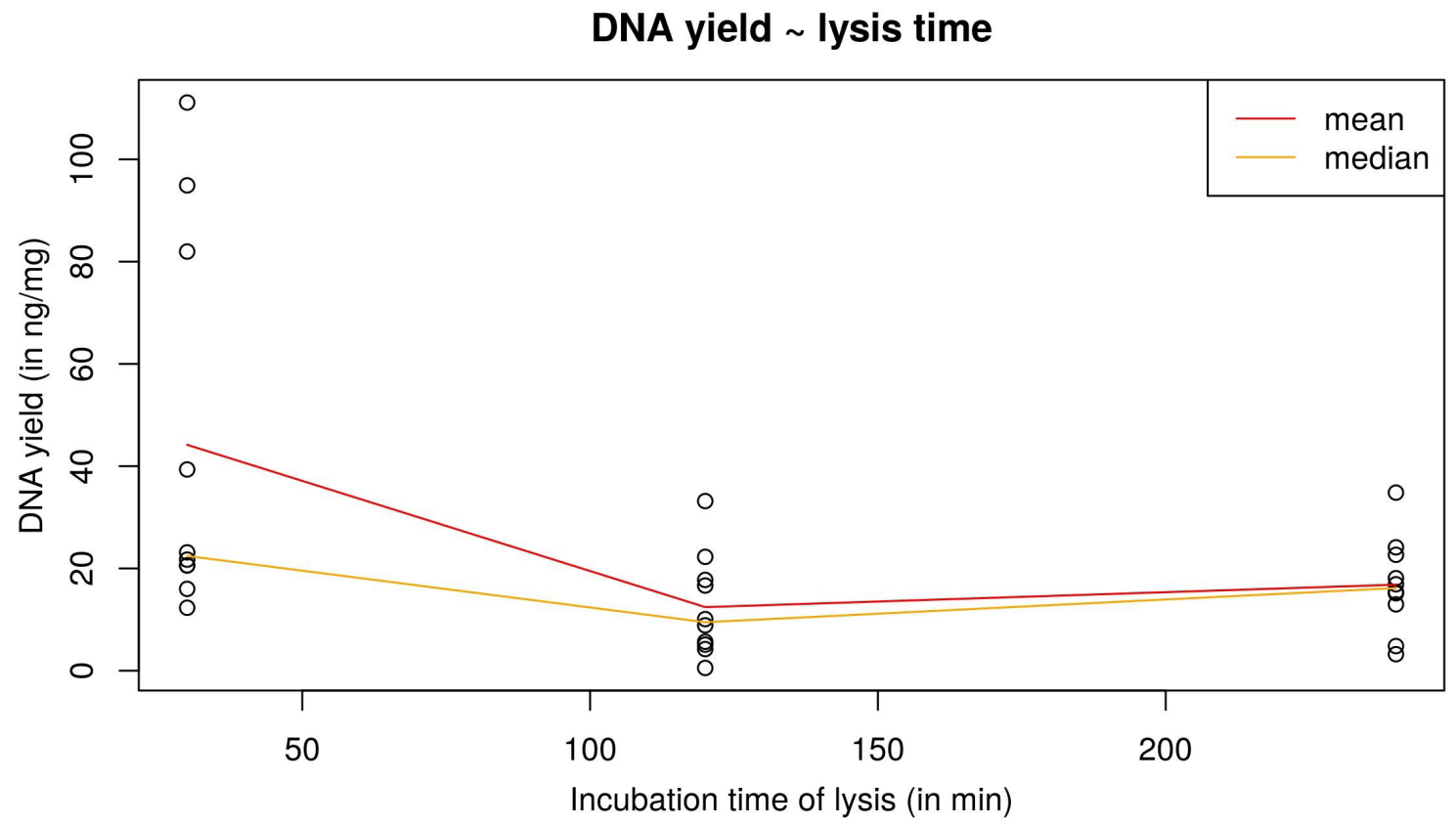

Fig. 6. DNA yield of the CTAB method against varying incubation times 
Contrastingly, the DNA quality differed significantly between the two DNA extraction methods. As shown in the full sample set and subsample set, the DNA solutions from the column-based DNA extraction method were much purer than those from the CTABbased protocol despite the extra cleaning step with paramagnetic beads. In the CTAB-based protocol, the A260/A280 values were not markedly below 1.8, thus indicating no contamination by proteins, phenols or other contaminants that absorb strongly near $280 \mathrm{~nm}$. However, the A260/A230 values were markedly below 2.0, which indicates a contamination with EDTA, carbohydrates and/or other phenols that absorb near $230 \mathrm{~nm}$ (Anonymous, 2013). This corresponds to previous observations that polysaccharides (e.g., cellulose) and polyphenolic compounds can often not be removed in CTAB protocols (Turaki et al., 2017; Kenyon et al., 2008). The higher purity of DNA extracted using column-based kits is supposed to be the result of more stringently washing since the DNA is captured by a glass fiber filter (OPS Diagnostics, 2018, https://opsdiagnostics.com/notes/protocols/spin column_plant_protocol.html).

An effect not considered thus far is that small fragments (below 100 bp) may be lost in column-based methods altogether as demonstrated in preliminary results (not shown). Previous studies have shown different results whereby smaller fragments (below $70 \mathrm{bp}$ ) were found to be retained (Anonymous, 2008). Additionally, Dabney et al. (2013) were able to sequence fragments as short as $30 \mathrm{bp}$ using a modified silica column-based protocol by Rohland and Hofreiter (2007). These short fragments are commonly included in studies of humans but may be less helpful in studies of species without a sequenced genome.

Furthermore, these short fragments are often excluded in size-selective DNA purification steps (Dabney et al., 2013). However, this purification step is absent in a recently developed single-stranded library preparation method (Meyer et al., 2012), thus making it possible to use $30 \mathrm{bp}$ long fragments (and with further improvements, potentially also $20 \mathrm{bp}$ long fragments) according to Dabney et al. (2013). An important consideration when dealing with old type material is how to reduce the amount of tissue used since $20 \mathrm{mg}$ leaf material may be highly destructive for small herbarium samples.

\section{Different incubation times}

Even though prolonged incubation times might increase the DNA yield and work better for other taxa (Drábková et al., 2002), this study found to the contrary. It was observed that after $2 \mathrm{~h}$ and $4 \mathrm{~h}$ incubation time, some samples included pigments (after the CTAB protocol but before the bead clean-up), which indicates an increase in contaminants since this was not the case when testing with a 30 min lysis step.

Nevertheless, the fact that DNA yield, A260/A280 and A260/A230 were all lower after $2 \mathrm{~h}$ in comparison to $30 \mathrm{~min}$ and $4 \mathrm{~h}$ indicates problems in this experiment. The reason for this might be that during the bead clean-up (after the ethanol washing) the pellets were air-dried under the fume hood with slightly different durations (for $5 \mathrm{~min}$ after $2 \mathrm{~h}$ lysis and $10 \mathrm{~min}$ after $4 \mathrm{~h}$ lysis). Thus, it seems to be advantageous to wait slightly longer to assure that all ethanol evaporated. However, the different bead solution used may be sufficient to explain this pattern. Future comparisons should aim at reducing these variables, which may seem slight but could be important regarding the little amount of DNA present in the specimens.

\section{Improving the comparison}

DNA extraction is a destructive method and sufficient yield requires sufficient amounts of starting material. Therefore, methods have been developed to reduce the destruction such as suggestions to rub material from leaves rather than use whole leaves (Shepherd, 2017). If herbarium specimens are partly destructed, one will guarantee that the material is used most efficiently, although there is a trade-off. We noticed that the CTAB protocol becomes difficult to process with just c. $10 \mathrm{mg}$ of leaf tissue since the DNA pellet became too small and too translucid to see if a pellet formed on the side of the tubes. Therefore, methods have been developed that more efficiently release DNA from the tissue (Kistler, 2012).

Apart from absolute DNA amounts recoverable from herbarium specimens, such DNA is often also highly degraded to short fragments. There are various steps in the DNA extraction that may degrade DNA even further. For example, paramagnetic bead-aided methods might increase the probability that DNA breaks due to mechanical forces and 2-phase DNA extractions might be an alternative (Mayland-Quellhorst, personal communication). Thus, there are obvious ways to improve DNA extraction and commercial companies have started to advertise such methods, such as "MagPure 
Plant DNA LQ Kit" (Biotech Angen Inc., Guangzhou, China), which needs just one centrifugation step after lysis to transfer the DNA containing supernatant into a new tube in which it is cleaned with paramagnetic beads. Even different commercial DNA extraction kits may result in different DNA yield and quality results (Albach, Dodsworth, unpublished data).

Another aspect deserving further investigation is whether DNA impurity as measured by a low 260/230 ratio is a problem for library preparation and DNA sequencing.

Further improvements are especially needed for controlling the intra-sample variation; therefore, we would need to collect larger quantities of leaf tissue per sample, grind these larger quantities, mixing it thoroughly and making equal aliquots of the leaf powder that are stored at $-20{ }^{\circ} \mathrm{C}$ before testing different DNA extraction methods.

\section{Acknowledgements}

This work was supported by the German Science Foundation, DFG priority program 1991, "Taxon-Omics". Additional support for the project came from the VW-Foundation, project 90256.

\section{REFERENCES}

Albach D.C., Chase M.W. Paraphyly of Veronica (Veroniceae; Scrophulariaceae): Evidence from the internal transcribed spacer (ITS) sequences of nuclear ribosomal DNA. Journal of Plant Research, 2001, 114: 9-18. https://doi. org/10.1007/PL00013971

Anonymous. MinElute ${ }^{\circledR}$ Handbook. Hilden, Germany: Qiagen GmbH, 2008, 48 pp. https://doi. org/10.1007/978-1-4939-3185-9_1

Anonymous. 260/280 and 260/230 Ratios. T042-Technical Bulletin Nano Drop Spectrophotometers. Wilmington, Delaware, USA: Thermo Scientific, 2013, 2 pp.

Arthofer W., Avtzis D.N., Riegler M., Stauffer C. Mitochondrial phylogenies in the light of pseudogenes and Wolbachia: re-assessment of a bark beetle dataset. ZooKeys, 2010, 58: 269-280. https://doi.org/10.3897/ zookeys.56.531

Blair C., Campbell C.R., Yoder A.D. Assessing the utility of whole genome amplified DNA for next-generation molecular ecology. Molecular Ecology Resources, 2015, 15: 1079-1090. https://doi.org/10.1111/1755-0998.12376

Carr S.M., Griffith O.M. Rapid isolation of animal mitochondrial DNA in a small fixed-angle rotor at ultrahigh speed. Biochemical Genetics, 1987, 25: 385390. https://doi.org/10.1007/BF00554547

Choi J., Lee H., Shipunov A. All that is gold does not glitter? Age, taxonomy, and ancient plant DNA quality. PeerJ, 2015, 3: e1087. https://doi.org/10.7717/peerj.1087
Chomicki G., Renner S.S. Watermelon origin solved with molecular phylogenetics including Linnaean material: another example of museomics. New Phytologist, 2015, 205: 526-532. https://doi.org/10.1111/nph.13163

Dabney J., Knapp M., Glocke I., Gansauge M.-T., Weihmann A., Nickel B., Valdiosera C., García N., Pääbo S., Arsuaga J.-L. Complete mitochondrial genome sequence of a Middle Pleistocene cave bear reconstructed from ultrashort DNA fragments. Proceedings of the National Academy of Sciences, 2013, 110(39): 15758-15763. https://doi.org/10.1073/pnas.1314445110

DeAngelis M.M., Wang D.G., Hawkins T.L. Solidphase reversible immobilization for the isolation of PCR products. Nucleic Acids Research, 1995, 23(22): 4742-4743.

Dodsworth S. Genome skimming for next-generation biodiversity analysis. Trends in Plant Science, 2015, 20: 525-527. https://doi.org/10.1016/j.tplants.2015.06.012

Dormann C.F., Kühn I. Angewandte Statistik für die biologischen Wissenschaften. $2^{\text {nd }}$ ed. Leipzig: Helmholtz Zentrum für Umweltforschung-UFZ, 2009, 223 pp.

Doyle J.J. Isolation of plant DNA from fresh tissue. Focus, 1990, 12: 13-15. https://doi.org/0.2225/ vol10-issue3-fulltext-5

Doyle J.J., Doyle J.L. A rapid DNA isolation procedure for small quantities of fresh leaf tissue. Phytochemical Bulletin, 1987, 19: 11-15.

Drábková L., J. Kirschner, Vlček C. Comparison of seven DNA extraction and amplification protocols in historical herbarium specimens of Juncaceae. Plant Molecular Biology Reporter, 2002, 20: 161-175. https://doi. org/10.1007/BF02799431

Dunn O.J. Multiple comparisons using rank sums. Technometrics, 1964, 6: 241-252.

Dwivedi M.D., Barfield S., Pandey A.K., Schaefer H. Phylogeny of Zehneria (Cucurbitaceae) with special focus on Asia. Taxon, 2018, 67: 55-65. https://doi. org/10.12705/671.4

Höpke J., Albach D.C. CTAB vs. column-based DNA extraction from old herbarium material. Visnyk of Lviv University. Ser. Biol., 2018, 78: 14-19.

Kenyon L., Lebas B., Seal S. Yams (Dioscorea spp.) from the South Pacific Islands contain many novel badnaviruses: implications for international movement of yam germplasm. Archives of Virology, 2008, 153: 877-889. https://doi.org/10.1007/s00705-008-0062-5

Kistler L. Ancient DNA Extraction from Plants. In: Ancient DNA: Methods and Protocols. B. Shapiro, M. Hofreiter. Totowa, NJ: Humana Press, 2012, pp. 71-79.

Klokov M.V. De Veronicis spicatis. In: Novosti sistematiki vysshikh i nizshikh rastenii (Kiev), [published in] 1976, [vol. of] 1975: 92-111. [Клоков М.В. О верониках колосистых. В кн.: Новости систематики высших и низших растений (Киев), 1975 (опубликовано 1976): 92-111].

Knapp M., Clarke A.C., Horsburgh K.A., MatisooSmith E.A. Setting the stage-Building and working in an ancient DNA laboratory. Annals of Anatomy-Anatomischer Anzeiger, 2012, 194: 3-6. https://doi.org/10.1016/j. aanat.2011.03.008 
Lage J.M., Leamon J.H., Pejovic T., Hamann S., Lacey M., Dillon D., Segraves R., Vossbrinck B., González A., Pinkel D. Whole genome analysis of genetic alterations in small DNA samples using hyperbranched strand displacement amplification and array-CGH. Genome Research, 2003, 13: 294-307. https://doi.org/10.1101/ gr.377203

Lasken R.S. Genomic DNA amplification by the multiple displacement amplification (MDA) method. Biochemical Society Transactions, 2009, 37: 450-453. https://doi. org/10.1042/BST0370450

Li J., Harris L., Mamon H., Kulke M.H., Liu W.-H., Zhu P., Makrigiorgos G.M. Whole genome amplification of plasma-circulating DNA enables expanded screening for allelic imbalance in plasma. The Journal of Molecular Diagnostics, 2006, 8: 22-30. https://doi.org/10.1373/ clinchem.2008.104612

Lovmar L., Syvänen A.C. Multiple displacement amplification to create a long-lasting source of DNA for genetic studies. Human Mutation, 2006, 27: 603-614. https://doi.org/10.1002/humu.20341

Maciejewska A., Jakubowska J., Pawłowski R. Whole genome amplification of degraded and nondegraded DNA for forensic purposes. International Journal of Legal Medicine, 2013, 127: 309-319. https://doi.org/10.1007/ s00414-012-0764-9

Meyer M., Kircher M., Gansauge M.-T., Li H., Racimo F., Mallick S., Schraiber J.G., Jay F., Prüfer K., De Filippo C. A high-coverage genome sequence from an archaic Denisovan individual. Science, 2012, 338: 222-226. https://doi.org/10.1126/science. 1224344

Ostapko V.M. On veronicas of Donbass. In: Introduktsiya $i$ akklimatizatsiya rasteniy (Kiev), 1985, 3: 18-25. [Остапко В.М. О верониках Донбасса. В кн.: Интродукция и акклиматизация растений, 1985, 3: 18-25].

Ostapko V.M. New species of Galium L. (Rubiaceae) and Veronica L. (Scrophulariaceae) from the Ukraine's South-East. Ukrayins'kyi Botanichnyi Zhurnal (Ukrainian Botanical Journal), 1994, 51(2/3): 84-91. [Остапко В.M. Нові види Galium L. (Rubiaceae) та Veronica L. (Scrophulariaceae) з Південного Сходу України. Український ботанічний журнал, 1994, 51(2/3): 84-91].

Ostapko V.M. New nomenclatural combinations and a new name in Pseudolysimachion (Plantaginaceae s. 1. = Veronicaceae s. str.) and Phlomoides (Lamiaceae): taxa occurring in Ukraine. Ukrainian Botanical Journal, 2014, 71: 673-675. https://doi.org/10.15407/ukrbotj71.06.673

Ostapko V.M., Boiko G.V., Mosyakin S.L. Vascular plants of the Southeast of Ukraine. Donetsk: Knowledge Publ., 2010, 247 pp. [Остапко В.М., Бойко А.В., Мося- кин С.Л. Сосудистые растения юго-востока Украины. Донецк: Ноулидж, 2010, 247 с.].

Rogers S.O., Bendich A.J. Extraction of DNA from milligram amounts of fresh, herbarium and mummified plant tissues. Plant Molecular Biology, 1985, 5: 69-76. https://doi.org/10.1007/BF0002008

Rohland N., Hofreiter M. Comparison and optimization of ancient DNA extraction. BioTechniques, 2007, 42: 343352. https://doi.org/10.2144/000112383

Schaefer H., Heibl C., Renner S.S. Gourds afloat: a dated phylogeny reveals an Asian origin of the gourd family (Cucurbitaceae) and numerous oversea dispersal events. Proceedings of the Royal Society of London B: Biological Sciences, 2009, 276: 843-851. https://doi.org/10.1098/ rspb.2008.1447

Shepherd L.D. A non-destructive DNA sampling technique for herbarium specimens. PLoSONE, 2017, 12: e0183555. https://doi.org/10.1371/journal.pone.0183555

Staats M., Cuenca A., Richardson J.E., Vrielink-van Ginkel R., Petersen G., Seberg O., Bakker F.T. DNA damage in plant herbarium tissue. PLoS ONE, 2011, 6: e28448. https://doi.org/10.1371/journal.pone.0028448

Turaki A., Ahmad B., Magaji U., Abdulrazak U., Yusuf B., Hamza A. Optimised cetyltrimethylammonium bromide (CTAB) DNA extraction method of plant leaf with high polysaccharide and polyphenolic compounds for downstream reliable molecular analyses. African Journal of Biotechnology, 2017, 16: 1354-1365. https://doi. org/10.5897/AJB2017.15942

Tzvelev N.N. Veronicas (Veronica L.) of the affinity of $V$. spicata L. and some problems of the phylogenesis of the genus. Byulleten Moskovskogo Obshchestva Ispytatelei Prirody. Otdel Biol., 1981, 86(6): 82-92. [Цвелев Н.Н. Вероники (Veronica L.) из родства V. spicata L. и некоторые вопросы филогении этого рода. Бюл. МОИП. Отд. биол., 1981, 86(6): 82-92].

Wang G., Maher E., Brennan C., Chin L., Leo C., Kaur M., Zhu P., Rook M., Wolfe J.L., Makrigiorgos G.M. DNA amplification method tolerant to sample degradation. Genome Research, 2004, 14: 2357-2366. https://doi. org/10.1101/gr.2813404

Záveská Drábková L. DNA extraction from herbarium specimens. In: Molecular Plant Taxonomy. P. Besse. Totowa, NJ: Humana Press, 2014, pp. 69-84.

Recommended for publication by S.L. Mosyakin 
Хьопке Я. ${ }^{1}$, Брюер Г. $^{2}$, Додсворт C. ${ }^{2,3}$, Ортіс E.M. ${ }^{4}$, Альбах Д.К. ${ }^{1}$ Виділення ДНК зі старих гербарних зразків представників Veronica subgen. Pseudolysimachium (Plantaginaceae). Укр. бот. журн., 2018, 75(6): 564-575.

${ }^{1}$ Інститут біології та наук про довкілля, Ольденбурзький університет ім. Карла фон Осецького

D-26111 Ольденбург, Німеччина

${ }^{2}$ Королівський ботанічний сад К'ю

Річмонд TW9 3DS, Велика Британія

${ }^{3}$ Природничий факультет, Берфордширський

університет

Лутон LU1 3JU, Велика Британія

${ }^{4}$ Мюнхенський технічний університет, Департамент екології та менеджменту екосистем

вул. Еміля Раманна 2, D-85354 Фрайзінг, Німеччина

Гербарні зразки стали важливим джерелом інформації для молекулярних досліджень біорізноманіття, і навіть виник термін "гербарна геноміка". Проте, отримання хороших зразків ДНК зі старих гербарних зразків все ще є складним завданням. На даний час методи екстракції ДНК зі старого гербарного матеріалу часто дозволяють отримати лише деградовану або фрагментовану ДНК. Такі методи обговорювалися у багатьох дослідженнях, зокрема, щодо вирішення проблеми подальшої фрагментації ДНК. Метою нашого дослідження було порівняння різних методів екстракції ДНК зі старих гербарних зразків представників Veronica subg. Pseudolysimachium. Один з цих методів - екстракція ДНК на основі СТАВ (цетилтриметиламоній бромід або цетил-триметил-бромід амонію) з наступним очищенням за допомогою парамагнітних гранул, що використовується у Лабораторії Джодрелла у Королівському ботанічному саду К'ю (Велика Британія). Цей метод порівнювався з модифікованою методикою NucleoSpin Plant II на основі силікагелевих колонок, що використовувалася у Технічному університеті Мюнхен-Фрайзінг (Німеччина) i була успішно застосована для отримання ДНК з типового зразка гербарію К. Ліннея. Проводилися подальші тести з вибіркою зразків щодо впливу часу інкубації на методику виділення ДНК за допомогою СТАВ. Наші попередні результати свідчать, що СТАВ-метод екстракції ДНК може мати певні переваги у конкретних випадках, але також вказують на те, що методи на основі силікагелевих колонок мають менше проблем із забрудненням полісахаридами та поліфенольними сполуками. Ми не виявили певної закономірності щодо часу інкубації, але розробили декілька ідей про те, як рухатися далі з експериментами для виявлення оптимальної методики екстракції ДНК для зразків, що містять фрагментовану ДНК. 3 практичного погляду, метод на основі колонок виглядає крашим, особливо тоді, коли є потреба зменшити кількість тканини листків. Проте, слід розробляти подальші вдосконалені модифікації обох методів.

Ключові слова: Veronica subg. Pseudolysimachium, гербарні зразки, методи екстракції ДНК, молекулярні дослідження
Хёпке Я. ${ }^{1}$, Брюэр Г. ${ }^{2}$, Додсворт С., ${ }^{2,3}$ Ортис Э.М. ${ }^{4}$, Альбах Д.К. ${ }^{1}$ Выделение ДНК из старых гербарных образцов представителей Veronica subgen. Pseudolysimachium (Plantaginaceae). Укр. бот. журн., 2018, 75(6): 564-575.

${ }^{1}$ Институт биологии и экологии, Ольденбургский университет им. Карла фон Осецкого

D-26111 Ольденбург, Германия

${ }^{2}$ Королевский ботанический сад Кью

Ричмонд TW9 3DS, Великобритания

${ }^{3}$ Факультет биологических наук, Берфордширский университет

Лутон LU1 3JU, Великобритания

${ }^{4}$ Мюнхенский технический университет, Департамент экологии и менеджмента экосистем ул. Эмиля Раманна 2, D-85354 Фрайзинг, Германия

Гербарные образцы стали важным источником информации для молекулярных исследований биоразнообразия; возник даже термин "гербарная геномика". Однако получение хороших образцов ДНК из старых гербарных образцов все еще является сложной задачей. В настоящее время методы экстракции ДНК из старого гербарного материала позволяют получить лишь деградированную или фрагментированную ДНК. Такие методы обсуждались во многих исследованиях, в частности, при решении проблемы дальнейшей фрагментации ДНК. Целью нашего исследования было сравнение различных методов экстракции ДНК из старых гербарных образцов представителей Veronica subg. Pseudolysimachium. Один из этих методов - экстракция ДНК на основе СТАВ (цетилтриметиламмоний бромид или цетил-триметил-бромид аммония) с последующей очисткой с помощью парамагнитных гранул используется в Лаборатории Джодрелла в Королевском ботаническом саду Кью (Beликобритания). Этот метод сравнивали с модифицированной методикой NucleoSpin Plant II на основе силикагелевих колонок, которая использовалась в Техническом университете Мюнхен-Фрайзинг (Германия) и была успешно применена для получения ДНК из типового образца гербария К. Линнея. Дальнейшие тесты проведены с выборкой образцов по влиянию времени инкубации на методику выделения ДНК с помошью СТАВ. Наши предварительные результаты свидетельствуют о том, что СТАВ-метод экстракции ДНК может обладать определенными преимуществами в конкретных случаях, но также указывают на то, что методы на основе силикагелевих колонок имеют меньше проблем с загрязнением полисахаридами и полифенольными соединениями. Мы не обнаружили определенной закономерности относительно времени инкубации, но разработали несколько идей о том, как двигаться дальше с экспериментами по выявлению оптимальной методики экстракции ДНК для образцов, содержащих фрагментированную ДНК. С практической точки зрения, метод на основе колонок является лучшим, особенно, когда необходимо уменьшить количество ткани листьев. Однако, следует разрабатывать дальнейшие усовершенствованные модификации обоих методов.

Ключевые слова: Veronica subg. Pseudolysimachium, гербарные образцы, методы экстракции ДНК, молекулярные исследования 


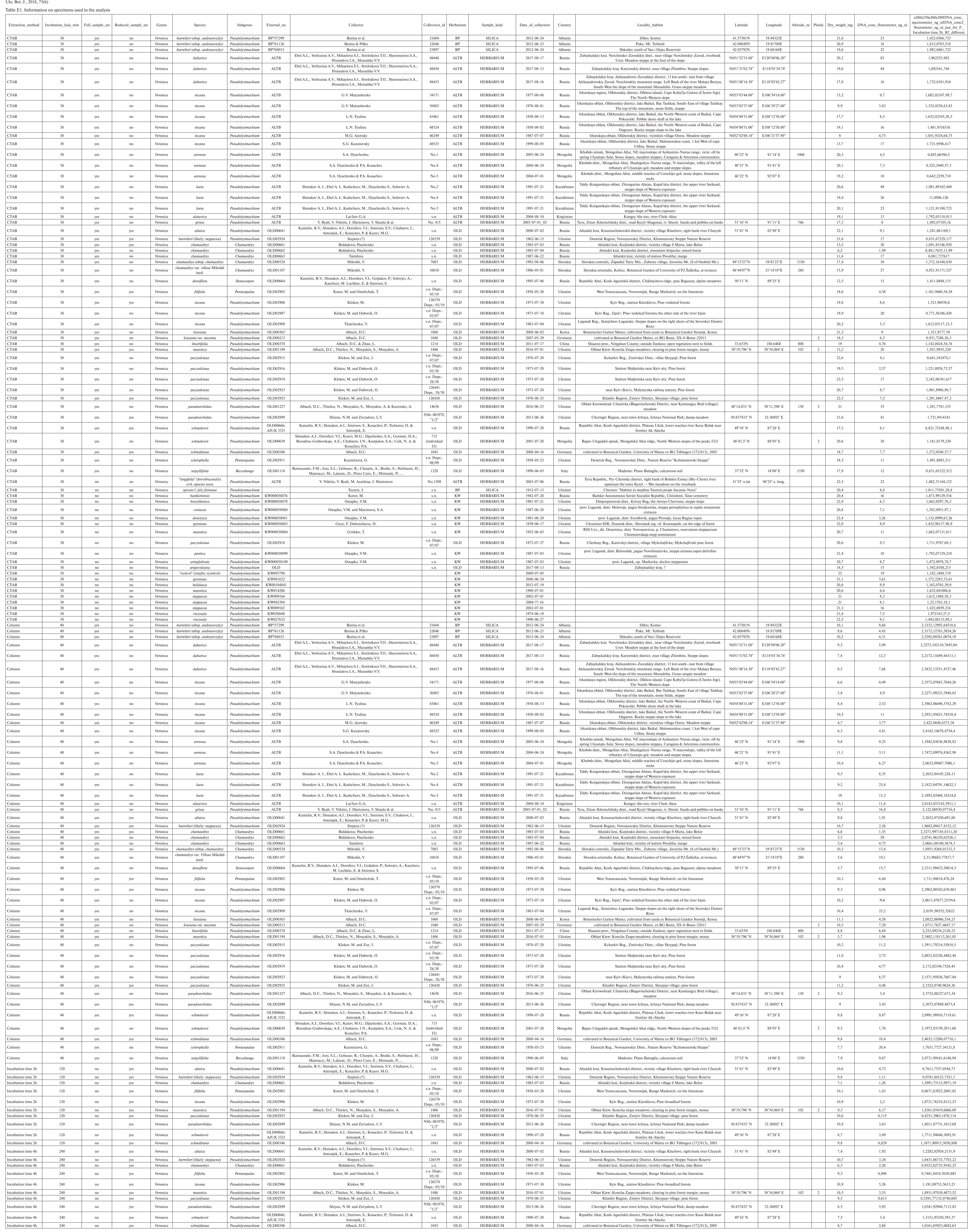

